\section{Research at Apia Observatory}

THE annual report for 1933 of the Apia Observatory, an institution which is controlled by the New Zealand Department of Scientific and Industrial Research, contains seismological, meteorological, magnetic and electrical data for Apia (western Samoa), and climatological summaries for a number of islands in the South Pacific. The electrical data refer to atmospheric electricity, and were obtained under the guidance of the Department of Terrestrial Magnetism at Washington, D.C., U.S.A., as in former years. They include observations made with Benndorf electrometers. A tide gauge was maintained, and copies of the tabular records were supplied to the United States Coast and Geodetic Survey at Washington. In the more ordinary meteorological work, seventy soundings were made with pilot balloons, to give information about the upper winds. Another activity in that section was the preparation of daily synoptic weather charts. The material for these was collected by Apia Radio Station. Twenty observing stations from various islands contributed to this, thus forming the nucleus of a synoptic network. Material of the kind included in this report forms the observational basis of text-books of world climatology, but the report keeps to the statistical type of presentation, no attempt being made to relate the results to those obtained in other parts of the world.

\section{Cancer Research at the Franklin Institute}

Av illustrated brochure has recently been published by the Biochemical Research Laboratories of the Franklin Institute, Philadelphia, describing the aims of the Foundation, which previously was known as the Cancer Research Laboratories. It is pointed out that research has extended from studies of cancer alone to other phases of life and disease, so that it appeared suitable that past research done on the cancer problem should be made an avenue of approach to the more general area of other diseases. The aims of the Foundation are the study of the processes of disease from a chemical point of view, the study of now organic chemical compounds with regard to their therapeutic, medicinal and beneficent values and the study of longevity and the diseases of age, with the hope of prolonging the span of life. The booklet points out that the investigators at the Institute work as a team, although grouped in the three departments of chemistry, physics and cytology : the director is Dr. Ellice McDonald. The library is an important feature of the Institute, with more than 16,000 classified reprints with author and subject reference. The brochure concludes with a list of $10 \mathrm{I}$ papers published during the past nine years from the Institute or the Cancer Research Laboratories.

\section{Standards of Telephone Transmission}

IN the Engineering Supplement to the Siemens Magazine of January, W. H. Grinsted discusses the problem of the standards used for the assessment of telephone transmission. The wide range of variation of many of the factors involved makes the problem a very complex one. The factors affecting trans- mission may be divided into the conditions associated with the users, including their own peculiarities, and the plant provided by the administration. Transmission is said to be satisfactory when two subseribers can converse without misunderstanding or strain. During the last four years, experiments have been made in the Siemens' laboratories on a method of transmission testing for 'satisfactoriness' based on this definition. Measurements of satisfactoriness are often made by sending speech to the limit of intelligibility or using nonsense syllables (logatomes), but neither represents conditions similar to normal operation. The latest American scheme is to use 'judgment observations', that is, personal preference as the criterion. The objection to this method is that different persons give very different reasons for preferring one circuit to another. In the method described by the author, the quality of the transmission is measured by noting the number of times that the listener's attention is diverted by the need for conscious effort to understand a word or phrase. The method is highly subjective, but this is necessary if it is to take into account some important factors. The limitations of the method are also discussed.

\section{Universities and War}

IN Great Britain there is some difference of opinion as to the purpose of university education. In Italy the question has been definitely settled. What follows is a translation of the beginning of the preface to "Nozioni di Balistica Esterna", by 'T. Levi-Civita and U. Amaldi (Zanichelli, Bologna, 1935) : "The Supreme Council of Defence has requested that University programmes of studies in every subject shall comprise, as an integral part of the course, the theories that more directly concern Military Science and Technique; and in particular has pointed out the claims of External Ballistics to be included in the Theoretical Mechanics Course. We have accordingly thought it our duty to complete with this appendix our Compendium of Theoretical Mechanies (Zanichelli, Bologna, 1928), which has been drawn up to conform with the programme of a regular course at a University or Higher Engineering College. The Contents of this Appendix faithfully follow the programme suggested by the aforesaid Supreme Council of Defence. . . ." We should like to see the corresponding programmes for other subjects, including theology. Presumably that for literature would include Nietzche's dictum "Man is made for War . . . ; all else is folly".

\section{Literature on Water and its Pollution}

A VALUABLE summary of abstracts of current research upon water and its pollution, prepared by the Water Pollution Staff of the Department of Scientific and Industrial Research, is issued monthly. In the January number (10, No. 1, 1937. H.M. Stationery Office. Price $2 s$. net) the matter deals with a variety of subjects grouped under "Water Supplies", "Analysis and Examination of Water", "Sewage", "Trade Wastes" and "Pollution of Natural Waters". The abstracts are fair summaries of the original literature. 